\title{
Drivers and Barriers of Mobile Phone Remanufacturing Business in Indonesia: Perspectives of Retailers
}

\author{
Didik Wahjudi ${ }^{*}$, Shu-san Gan ${ }^{1}$, Yopi Yusuf Tanoto ${ }^{1}$, Jerry Winata ${ }^{1}$, and Benny Tjahjono ${ }^{2}$ \\ 1) Department of Mechanical Engineering, Petra Christian University, Jl. Siwalankerto 121-131, \\ Surabaya 60236, Indonesia \\ ${ }^{2)}$ Centre for Business in Society, Coventry University, Coventry CV1 5FB, United Kingdom
}

\begin{abstract}
Remanufacturing is deemed to be effective in reducing WEEE. Existing studies on remanufacturing mostly focus on operational issues, product acquisition, and pricing. However, some doubts about remanufacturing business arise in developing countries, where there is less regulation on remanufacturing and less environmental awareness. This study aims to investigate the prospects of remanufacturing business from the retailers' perspectives through in-depth interviews on three retailers in Surabaya, Indonesia. The main drivers for mobile phone remanufacturing business are its affordable and competitive price, big demand for popular mobile phones and high-end mobile phone, the opportunity for specification upgrade, and its suitability with the needs of Indonesian people. The main barriers for remanufacturing business are the possibility for cannibalizing new mobile phones' market share, the uncertainty of core supply, discontinuity of replacement part supply, lack of product knowledge among consumers and retailers, hesitation of retailers to sell remanufactured products, and lack of strict and clear regulations about remanufacturing business. Findings of this study provide insights to prospective mobile phone remanufacturers of what needs to be tackled to start a prosperous business. On the theoretical side, it provides complementary knowledge to existing studies that have been conducted mostly on countries that have higher environmental awareness.
\end{abstract}

Keywords: case study, closed-loop supply chain, short-life cycle product, waste electrical and electronic equipment (WEEE)

\section{Introduction}

The use of mobile phones results in much amount of waste electrical and electronic equipment (WEEE). Indonesia has the fourth-largest mobile phone users in the world [1]. Coupled with the fact that mobile phone users change their phone every year [2], an increasing amount of end-of-use mobile phones becomes a serious problem that needs to be tackled. Remanufacturing is an effective solution for WEEE problems. Not only it conserves energy and virgin materials usage, but also it reduces landfill significantly [3]. While remanufacturing is a common practice and becomes a huge business in the US and European countries $[4,5]$, it is still in the embryonic stage in Indonesia. Even though refurbished black and white photocopiers comprise $60 \%$ to $70 \%$ of Indonesian photocopier market [6], it is hard to find remanufactured photocopier in the Indonesian market. Refurbished products are different from remanufactured ones in terms of price, quality, and warranty. Remanufactured product has a price of $45 \%$ to $70 \%$ of comparable

\footnotetext{
* Corresponding author: dwahjudi@petra.ac.id
} 
new products [7, 8], while refurbished photocopiers can only be sold around $20 \%$ of new products [6]. Quality of remanufactured products is claimed to be as good as new products and with the level of disassembly at the part level [4]. Furthermore, remanufactured products are furnished with a warranty as that of new products [7]. It is worth investigating why some firms prefer to do refurbishing business instead of the more profitable remanufacturing business. This paper aims to investigate drivers and barriers of mobile phone remanufacturing in Indonesia from the perspectives of retailers. The fact that drivers and barriers for remanufacturing business are region-dependent [9] means this study can help to provide insights to prospective remanufacturers and policymakers. The rest of the paper is structured as follows. Literature review on the closed-loop supply chain, mobile phone recovery management, and drivers and barriers of remanufacturing is provided in Section 2. Section 3 describes the research methodology used in the study. Section 4 provides results and discussion of findings. Finally, conclusions, limitations, and recommendations for future research are presented in Section 5.

\section{Literature review}

\subsection{Recovery management of mobile phones}

Study on product recovery management (PRM) has been done by [10]. At the earlier stage, used products were incinerated or landfilled. The increasing customers' environmental awareness and rising product disposal costs compel manufacturers to reduce the quantities of waste. Governments such as the USA and European Union countries support this initiative by enforcing disposal bans for specific products, recycling mandates and goals, and product take-back requirements. For example, EU WEEE Directive requires $75 \%$ per weight of a mobile phone to be recovered [11]. This recovery includes components or the whole product reuse, materials recycling, and energy recovery. In addition, governments encourage the purchase of reusable products and products that have reused content. With pressure from customers and obligation from the government, the situation has changed. Manufacturers start to implement product recovery management, a program that aims to recover the economic value of products as much as possible and to minimize quantities of waste. End-of-life (EOL) products can be obtained through several channels such as takeback program, off-lease or off-rent return, broken product return, and buy-back program. The enforcement of the rapidly changing environmental regulations poses a threat to some companies. On the contrary, it also creates business opportunities for companies that successfully embrace these environmental requirements by offering environmental-friendly products [10].

Fast change of mobile phone technology and consumer demand presents a problem of mounting waste electrical and electronic equipment (WEEE). There are two distinctive characteristics of a mobile phone compared to other WEEEs [12]. Firstly, the number of end-of-use mobile phones grows much faster than other types of electrical and electronic equipment. Secondly, mobile phones have a flourishing second-hand market. The main reason for the mobile phone's retirement is to be replaced by new models. While mobile phones have an expected lifetime of $10 \mathrm{yr}$, average mobile phones are replaced every year [2]. Several parties are involved in the recovery of retired mobile phones among other local government agencies, OEMs, outsourced service providers of OEMs and network providers, and independent collectors. These third parties and independent collectors are the predominant sources of retired mobile phones [12]. Geyer and Blass [12] argue that only small fraction of retired mobile phones is recovered, even it is less than $20 \%$ because most 
cell phone users tend to keep their old mobile phones rather than returning them through a collection agency.

Figure 1 illustrates the recovery management that a mobile phone can experience in a closed-loop supply chain. Collected mobile phones are reused as is, refurbished, remanufactured, and recycled. Reuse is a process of using a functional product after the product no longer satisfies the first user, either for communication function or other functions [13, 14]. However, reuse sometimes refers to a broad category of product recovery that includes reuse by different users, reuse for other purposes, refurbishing, and remanufacturing such as in [12]. Used mobile phones can be utilized for other functions such as home alarm systems, wildlife detection, and tracking systems, earthquake monitoring systems, GPS trackers for mobility measurement, and educational purpose [14]. In addition, mobile phones' spare parts are reused as replacement parts especially in the developing countries. Refurbishing/reconditioning is defined as a process of restoring a product to a satisfactory state, that is lower than the quality of the new product [13]. Remanufacturing is a process of transforming a retired product into like-new condition, equipped with a warranty that is comparable with the warranty of new product $[4,7]$. In recycling, the material value of the product is recovered by transforming it into a material with the same quality as the new material or lower [13].

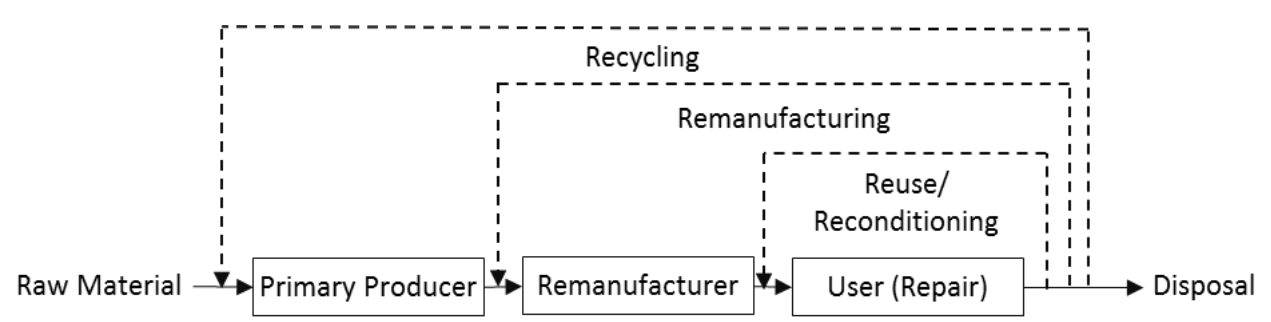

Fig. 1. Types of closed-loop supply chain

At the processing center, collected EoL mobile phones are inspected and sorted to determine whether the handsets can be refurbished/remanufactured, or they must be recycled. The option to recycle retired mobile phones is not a preferable alternative because recycling can only recover $12 \%$ to $19 \%$ of the total phone mass in the form of copper and precious metals [12]. Refurbishing and remanufacturing are two terms that are often used interchangeably. However, Gaur et al. [4] underline two differences between refurbishing and remanufacturing. First, remanufacturing has a deeper disassembly level, i.e. at the component level, compared to at the module level for refurbishing. Second, remanufactured mobile phones are equipped with a warranty, which refurbished ones do not have. In practice, the refurbishing process varies greatly from simple testing to genuine repair or reconditioning [12]. On the contrary, the remanufacturing process follows a stricter procedure to ensure like-new quality. Remanufactured phones are sold to developing and emerging countries in accordance with the telecommunication technology used in the country of origin of the mobile phones. That is why remanufactured phones from the UK are exported to Africa, the Far East, the Middle East, and Eastern Europe, while remanufactured phones from the USA are sold to Latin America, Africa, Asia, and Eastern Europe or within the USA [12]. Mobile phones that cannot be remanufactured are recycled. That is why mobile phone remanufacturing and recycling are usually performed by the same enterprise [12]. However, remanufacturing is much more recommended than recycling because it preserves a product's value-added and makes a greater economic contribution [15].

The recent development of EoL treatment of mobile phones is discussed in [11]. EoL product management can be made more efficient and affordable by shifting the 
responsibility of the producer to the product. This scheme can be achieved through information technology and product design. Basic information on how to handle the products' EoL can provide in the forms of a label, universal product code (UPC), bar code, or radio frequency identification (RFID) tags. In addition to the above-mentioned treatment, product design of mobile phones can also be improved to reduce size and weight, prolong products life, increase component reuse, and accomplish sustainable product and material flow cycles [11].

\subsection{Drivers and barriers of remanufacturing}

Drivers and barriers of remanufacturing business have been investigated by several authors [9, 15-18]. Rathore et al. [15] argue that the availability of low-cost labor, price-sensitive market, and environmental awareness can drive remanufacturing business. On the other hand, a complicated and expensive reverse logistics system, misunderstanding of remanufactured products' quality and price, and a lack of legal obligation hinder the growth of remanufacturing business. Sharma et al. [16] identify environmental, economic, and social drivers for remanufacturing in India. Competitive price and preserved value-added are the main economic drivers. The key environmental drivers include the best way of product recovery and conservation of resources, while positive societal concerned image and more job opportunities are the crucial social drivers. They find quality concerns, lack of policy and regulation for remanufacturing, and negative end-user perception to be the substantial barriers of remanufacturing business in India [16].

Wang et al. [17] conduct an empirical study on drivers and barriers of the remanufacturing industry in China. They classify divers of remanufacturing business into economic factors, strategic factors, environmental policy factors, and technical factors, while they summarize the barriers as policy, technical, economic, social recognition, and industry environment. They argue enterprise strategy factor, policy and technical factors, and economic factor to be the main drivers for the remanufacturing industry. In addition, Wang, et al. [17] indicate the policy \& economic factors and industrial environmental factor to be the main hindrances for growth of remanufacturing business.

Lundmark et al. [18] summarize motives and challenges for remanufacturing business. The motives for remanufacturing business can be categorized into three categories, i.e. moral and ethical responsibility, environmental and legislation, and profitability, while challenges for remanufacturing can be classified as collection, remanufacturing process, and redistribution. Collection issues include balancing the supply of used products with the demand for remanufactured products. In addition, the lack of control is not only regarding quantity but also regarding the quality and timing of supply of used products [18]. Guide [19] claims it is very hard to estimate flow times and lead-times of remanufacturing process accurately because of the variance in the quality of the returned products. Challenge in redistribution includes uncertain demand and complexity $[18,19]$.

Wei et al. [9] identify environmental and ethical responsibility, customer orientation, and strategic advantage to be the main motives for remanufacturing business in China. On the other hand, they argue that customer recognition, legislation restrictions, and lack of sales channels are the main barriers for remanufacturing in China. Comparing car parts remanufacturing with machinery remanufacturing, Wei et al. [9] also indicate the difference of motives and barriers between car parts and machinery remanufacturing. Warranty is the third most important motive for car part remanufacturers, while it is not an important factor in the machinery remanufacturing [9].

\section{Research methodology}


The case study method was used to investigate drivers and barriers of mobile phone remanufacturing from perspectives of retailers. To ensure the reliability and validity of this case study, a protocol was developed to guide the interview. The protocol included questions about respondents' demographic information, familiarity with remanufactured products, and drivers and barriers for remanufacturing business. Three respondents from different background were interviewed in this study. Each interview took about $45 \mathrm{~min}$ and was recorded. The audio record was transcribed and coded using NVivo software. A description of mobile phone remanufacturing was given to each respondent because there was no mobile phone remanufacturing in Indonesia. Table 1 provides the demographics of respondents.

Table 1. Demographics of respondents

\begin{tabular}{clll}
\hline Retailer & \multicolumn{1}{c}{ Company } & \multicolumn{1}{c}{ Length of employment } & \multicolumn{1}{c}{ Position } \\
\hline R1 & IT Store & More than 5 yr & Branch manager \\
R2 & Mobile phone retailer & Between $3 \mathrm{yr}$ to $5 \mathrm{yr}$ & Owner \\
R3 & Mobile phone retailer & More than 5 yr & Supervisor \\
\hline
\end{tabular}

\section{Results and discussions}

The text was coded using NVivo software to identify recurring themes. The resulted codes were discussed with other research team members to improve the reliability and validity of the study [20]. Fifteen codes were discovered and classified into six drivers and nine barriers. Table 2 provides the list of drivers of mobile phone remanufacturing with their supporting codes and respective quotations, while Table 3 provides the list of barriers with their supporting codes and respective quotations.

\subsection{Drivers of mobile phone remanufacturing business in Indonesia}

There are six drivers identified in this study. Those six drivers can be classified into financial benefit, quality benefit, and social benefit. Among drivers that are identified in this study, some drivers have been identified by previous studies such as competitive and affordable price $[15,16,21]$ and profitability $[9,16,18]$. However, there are several previously identified drivers that we do not identify such as environmental awareness [9, 15-18], legislation and ethical responsibility [9, 18], and strategic advantage [9]. All these drivers are not identified because most of the Indonesian people have low environmental awareness [22]. In addition, there is no strict legislation that can drive remanufacturing practice in Indonesia [23].

That is why remanufacturing business in Indonesia is more focused on economic drivers. In this study identifies remanufacturing business drivers that are not identified in previous studies. First, the retailers claim there is a big demand for market-leading mobile phones, high-end mobile phones from popular brands, and for discontinued mobile phones. The high-end mobile phones are not affordable to lower-class segment in Indonesia. The availability of remanufactured high-end mobile phones may satisfy the needs of this segment. Second, the retailers confirm that like-new quality and upgraded specification are the features that prospective consumers are looking for. Third, retailers argue that remanufacturing can accommodate the needs of Indonesian people who are looking for affordable and cheap mobile phones with good features and performance. 
Table 2. List of drivers with their respective codes and quotations

\begin{tabular}{|c|c|c|}
\hline Benefit & Driver codes & Quotation from interviews \\
\hline \multirow[t]{3}{*}{ Financial } & High demand & $\begin{array}{l}\text { Big demand for mobile phone with a big market } \\
\text { share } \\
\text { Big demand for high-end mobile phone from } \\
\text { popular brand } \\
\text { Significant demand for old mobile phones that are } \\
\text { no longer produced }\end{array}$ \\
\hline & Competitive price & $\begin{array}{l}\text { Competitive price } \\
\text { Very marketable because of the affordable price } \\
\text { like-new quality } \\
\text { Affordable and competitive price }\end{array}$ \\
\hline & Profit & $\begin{array}{l}\text { More profit if the remanufacturing cost can be kept } \\
\text { very low }\end{array}$ \\
\hline \multirow[t]{2}{*}{ Quality } & Upgraded spec & Opportunity for specification upgrade \\
\hline & Perceived quality & Very marketable because of the like-new quality \\
\hline Social & Social expectation & $\begin{array}{l}\text { Very suitable for Indonesian market because it } \\
\text { matches the needs of Indonesian people }\end{array}$ \\
\hline
\end{tabular}

\subsection{Barriers of mobile phone remanufacturing business in Indonesia}

Barriers of mobile phone remanufacturing business can be classified into financial, legislation, social, and operational risks. The primary barrier according to the interviewed retailers is the hesitation of retailers to sell the remanufactured mobile phones. This hesitation may come from the long turnover when selling remanufactured mobile phones, uncertainty in price and quality, and lack of product knowledge among retailers and consumers. This barrier is similar to the finding of Rathore et al. [15], Sharma et al. [16], Wei et al. [9], and Wahjudi, et al. [21] that identify lack of awareness of remanufactured products' quality and price as a barrier of remanufacturing business.

These retailers also argue that the distribution of remanufactured mobile phones may cannibalize the market share of new mobile phones. This problem has been discussed by previous studies such as Guide and Li [24] and Atasu et al. [25]. Guide and Li [24] identify the big potential for cannibalization for the commercial product, but this potential is very small for the consumer product. This study highlights the fact that not all mobile phones are suitable to be remanufactured. Only certain models of certain brands may have good prospects. Obsolescence concern is another barrier for mobile phone remanufacturing. Remanufactured mobile phones may no longer be attractive to the prospective buyers because of the discontinued model or scarcity of replacement parts. The availability of a service center may alleviate the quality risk as reported by van Weelden et al. [26]. On the other hand, the unavailability of the service center will exacerbate the quality risk.

Government regulation is absolutely needed as identified by Sharma et al. [16] and Wei et al. [9]. The weak legislation is identified to be a significant barrier for remanufacturing business. The retailers emphasize the importance of consumer protection against fake products, especially during online purchase. The retailers also identify fear of the uncertain amount of tax the remanufacturers need to pay. This may cause hesitation to do remanufacturing business.

This study indicates remanufactured products may not be attractive to consumers that concern much about prestige. This especially applies to middle and upper-middle-class consumers that tend to be consumptive and very brand-conscious to show their prestige. 
The retailers also have a concern about the continuity of core supply. Previous studies argue the supply of core is very hard to control [18].

Table 3. List of barriers with their respective codes and quotations

\begin{tabular}{|c|c|c|}
\hline Risks & Barrier codes & Quotation from interviews \\
\hline \multirow[t]{5}{*}{ Financial } & Hesitation of retailers & $\begin{array}{l}\text { Quicker turnover in selling used mobile phones } \\
\text { Uncertainty in price and quality. How much can it be cheaper } \\
\text { and better than used products? } \\
\text { Lack of product knowledge among retailers. They may prefer } \\
\text { to sell used products instead of remanufactured products } \\
\text { Difficulty to describe remanufactured mobile phones to } \\
\text { consumers because of lack of product knowledge }\end{array}$ \\
\hline & Cannibalization & Needs a firm strategy to avoid cannibalizing new products \\
\hline & Market share & Only applicable to some brands, especially famous brands \\
\hline & Obsolescence & $\begin{array}{l}\text { Obsolescence of products } \\
\text { Fear of supply of replacement part continuity }\end{array}$ \\
\hline & Customer support & Unavailability of service center \\
\hline \multirow[t]{2}{*}{ Legislation } & Consumer protection & $\begin{array}{l}\text { Sales through online shop may create problems because } \\
\text { consumers cannot detect its originality } \\
\text { Lack of clear regulation } \\
\text { Fake remanufactured products }\end{array}$ \\
\hline & Governmental support & Strict regulations such as customs and excises \\
\hline Social & Prestige concern & $\begin{array}{l}\text { Acceptability of remanufactured mobile phones by all } \\
\text { segments }\end{array}$ \\
\hline Operations & Continuity of supply & Uncertainty of core supply \\
\hline
\end{tabular}

\subsection{Discussion of findings}

This study aims to investigate drivers and barriers of mobile phone remanufacturing in Indonesia. The drivers are classified as financial, quality, and social benefits. The barriers are identified as financial, legislation, social, and operational risks. Indonesia is known for its low labor cost, which is suitable for remanufacturing business [15]. Even though there were only three retailers involved, this study provides significant insight into prospective mobile phone remanufacturers and government agencies. First, this study provides information on what segment the remanufactured mobile phone should focus on and what kind of mobile phones is suitable to be remanufactured. In addition, this study offers recommendation on what features that are expected from the remanufactured mobile phones. Upgraded specification and affordable price are the two characteristics expected from the remanufactured mobile phones. Finally, this study encourages government agencies to promote remanufacturing as a method to reduce consumption of virgin material and energy and to reduce landfilling of WEEE. Public education on remanufacturing is essential to support remanufacturing business as well as the protection of consumers and remanufacturers.

\section{Conclusion, limitations, and recommendations for future research}

This study aims to identify drivers and barriers of mobile phone remanufacturing in Indonesia. In-depth interviews involving three mobile phone retailers identify six drivers 
and nine barriers of mobile phone remanufacturing. The primary drivers for mobile phone remanufacturing in Indonesia are financial benefits such as high demand, competitive price, and profit. These drivers are supported by quality benefit, i.e., like-new quality and upgraded specification. On the other hand, financial risks and legislation-related risks are the main barriers for mobile phone remanufacturing in Indonesia.

The managerial implication of this study is that remanufacturers should focus on lowerclass segment. Affordable high-end remanufactured phones with the upgraded specification are very attractive to this market segment. The other implication is related to government agencies. This study highlights the urgent need for public education on remanufacturing as well as legal protection of consumers and remanufacturers. Without government intervention, the mobile phone remanufacturing will not thrive in Indonesia.

Two research limitations are identified. The first limitation is that we do not conduct this study in the real market setting due to the unavailability of real remanufactured mobile phones in Indonesia. The second limitation deals with the limited number of respondents that makes the list of drivers and barriers is inexhaustive. Recommendation for future research is to follow up this study with a survey to identify the most dominant drivers and barriers.

\section{References}

1. Central Intelligence Agency. The world factbook: Telephones - mobile cellular. [Online] from https://www.cia.gov/library/publications/the-worldfactbook/rankorder/2151rank.html (2016). [Accessed on June 18 2016]

2. V.D.R. Guide Jr and L.N. Van Wassenhove, Oper. Res., 57,1:10-18(2009). https://pubsonline.informs.org/doi/abs/10.1287/opre.1080.0628

3. W.L. Ijomah, C.A. McMahon, G.P. Hammond, S.T. Newman, Int. J. Prod. Res, 45,18:4513-4536(2007). https://www.tandfonline.com/doi/abs/10.1080/00207540701450138

4. J. Gaur, M. Amini, P. Banerjee, R. Gupta, Qual. Mark. Res., 18,1:30-47 (2015). https://www.emeraldinsight.com/doi/abs/10.1108/QMR-01-2014-0001

5. D. Parker, K. Riley, S. Robinson, H. Symington, J. Tewson, K. Jansson et al., Remanufacturing market study, VTT Technical Research Centre of Finland, Finland (2015). p. 146. https://cris.vtt.fi/en/publications/remanufacturing-market$\underline{\text { study }}$

6. K. Kamigaki, M. Matsumoto, Y.A. Fatimah, Remanufacturing and refurbishing in developed and developing countries in Asia - A case study in photocopiers, The 24th CIRP Conference on Life Cycle Engineering, (Kamakura, Japan, 2017). Procedia CIRP, 61:645-650(2017). https://www.sciencedirect.com/science/article/pii/S2212827116313920

7. G.I. Zlamparet, W. Ijomah, Y. Miao, A.K. Awasthi, X. Zeng, J. Li, J. Clean. Prod., 149:126-136(2017).

https://www.sciencedirect.com/science/article/pii/S0959652617302081

8. R.T. Lund, W.M. Hauser, Remanufacturing - An American perspective. Paper presented at $5^{\text {th }}$ International Conference on Responsive Manufacturing - Green Manufacturing (ICRM 2010), (Ningbo, China, 2010). p. 1-6. https://digitallibrary.theiet.org/content/conferences/10.1049/cp.2010.0404

9. S. Wei, D. Cheng, E. Sundin, O. Tang, J. Clean. Prod., 94:340-351(2015). https://www.sciencedirect.com/science/article/pii/S0959652615001183

10. M. Thierry, M. Salomon, J.V. Nunen, L.V. Wassenhove, Calif. Manage. Rev., 37,2: 114-136 (1995). https://journals.sagepub.com/doi/pdf/10.2307/41165792 
11. O. Osibanjo, I.C. Nnorom, Environ. Impact Assess. Rev., 28,2-3:198-213(2008). https://www.sciencedirect.com/science/article/pii/S0195925507000789

12. R. Geyer, V.D. Blass, Int. J. Adv. Manuf. Tech., 47,5-8:515-525(2010). https://link.springer.com/article/10.1007/s00170-009-2228-Z

13. W.L. Ijomah, J.P. Bennett, J. Pearce, Remanufacturing: Evidence of environmental conscious business practice in UK," The Proceedings First International Symposium on Environmentally Conscious Design and Inverse Manufacturing, (Tokyo, Japan, 1999). https://ieeexplore.ieee.org/abstract/document/747607/

14. X. Li et al., Smartphone evolution and reuse: Establishing a more sustainable model, 39th International Conference on Parallel Processing Workshops, (San Diego, CA, 2010), p. 476-484.

https://ieeexplore.ieee.org/abstract/document/5599108

15. P. Rathore, S. Kota, A. Chakrabarti, J. Clean. Prod., 19,15:1709-1722(2011). https://www.sciencedirect.com/science/article/pii/S0959652611002277

16. V. Sharma, S.K. Garg, P.B. Sharma, J. Clean. Prod., 112,3:1882-1892 (2016). https://www.sciencedirect.com/science/article/pii/S095965261401302X

17. Y. Wang, L. Zhang, C. Zhang, A.S. Jeeva, Int. J. Ind. Eng-Theory, 22,1:35-45(2015). http://journals.sfu.ca/ijietap/index.php/ijie/article/view/1269

18. P. Lundmark, E. Sundin, M. Björkman, Industrial challenges within the remanufacturing system, The 3rd Swedish Production Symposium 2009, (Göteborg, 2009), pp. 132-138. http://www.divaportal.org/smash/record.jsf?pid=diva2:375722

19. V.D.R. Guide, Jr., Journal of Operations Management, 18,4:467-483(2000). https://www.sciencedirect.com/science/article/pii/S0272696300000346

20. R.K. Yin, Case study research: Design and methods, 4th edition ed. (Thousand Oaks, CA: SAGE Publications, Inc., 2009).

https://www.academia.edu/13784473/Case_study_research_design_and_methods 4th ed Robert_Yin

21. D. Wahjudi, S.-S. Gan, J. Anggono, Y.Y. Tanoto, International Journal of Business and Society, 19,2:415-428(2018). http://www.ijbs.unimas.my/images/repository/pdf/Vol19-no2-paper11.pdf

22. Y.A. Fatimah, Remanufacturing as a Potential Means of Attaining Sustainable Industrial Development in Indonesia, [Doctor of Philosophy] (School of Civil and Mechanical Engineering, Curtin University, Perth, Australia, 2014). https://espace.curtin.edu.au/handle/20.500.11937/2213

23. Y.A. Fatimah, W. Biswas, I. Mazhar, M.N. Islam, Journal of Remanufacturing, 3,6: 1-11(2013). https://link.springer.com/article/10.1186/2210-4690-3-6

24. V.D.R. Guide, Jr., J. Li, Decision Sciences, 41,3:547-572(2010). https://onlinelibrary.wiley.com/doi/abs/10.1111/j.1540-5915.2010.00280.x

25. Atasu, V.D.R. Guide, Jr., L.N. California Management Review, 52,2: 1-21(2010). https://journals.sagepub.com/doi/pdf/10.1525/cmr.2010.52.2.56

26. E. van Weelden, R. Mugge, C. Bakker, J. Clean. Prod., 113:743-754(2016). https://www.sciencedirect.com/science/article/pii/S095965261501731X 